\title{
Productivity Shocks and Nominal Exchange Rate Variability: a Case Study of Pakistan
}

\author{
Muhammad Zakaria \\ Quaid-i-Azam University \\ Eatzaz Ahmad \\ Quaid-i-Azam University
}

\begin{abstract}
This paper empirically examines the impact of productivity shocks on nominal exchange rate movements of Pak-rupee against currencies of its major trading partners using quarterly time-series data for the flexible exchange rate period (1983Q1 to 2006Q4). By taking into account the endogeneity problem the Generalized Method of Moments (GMM) provides results that are consistent with the theoretical predictions. The results suggest that variability in bilateral nominal exchange rates is explained in part by relative productivity differentials in the tradable and nontradable sectors both at home and abroad.
\end{abstract}

- JEL Classification : C22, C51, F31

- Key Words: nominal exchange rates, productivity, relative prices

\section{Introduction}

To explain exchange rate movements under the modern float, many economists resort to models in which real shocks play the dominant role. Some of the important channels that allow real shocks to affect exchange rate movements are sectoral relative productivity shocks. Productivity differences between countries

\footnotetext{
*Corresponding address: Muhanmmad Zakaria: Department of Economics, Quaid-i-Azam University, Islamabad, 45320, Pakistan, e-mail: mzakaria80@yahoo.com, Eatzaz Ahmad: Department of Economics, Quaid-i-Azam University, Islamabad, 45320, Pakistan

(2009-Center for International Economics, Sejong Institution, Sejong University, All Rights Reserved.
} 
have been shown to be an important reason for a systematic divergence between purchasing power parity and the equilibrium exchange rates (Cassel, 1918; Harrod, 1933; Balassa, 1964; Samuelson, 1964). ${ }^{1}$ Practically, it has also been observed that the currencies of high-tech countries appreciate. An over-valuation of Japanese exchange rate is generally quoted as an example. Since Japan has experienced high productivity in traded goods sector than the United States after the Second World War, yen witnessed real appreciation against dollar (Marston, 1986; Rogoff, 1996). There are a number of reasons to resurrect relative productivity differential hypothesis ${ }^{2}$ in flexible exchange rate regime. First, relative factor productivity is an important determinant of the long-run economic growth and prosperity of a country. Second, productivity shocks are exogenous variables that may play a key role in explaining movements in exchange rates. Third, in recent years, the extension of real business cycles models to the open economy has stimulated interest in technology shock effects.

Productivity bias hypothesis is based on the notion that purchasing power parity holds in tradable goods sector. Thus, the small open country's tradable goods' prices are determined internationally while the prices of nontradable goods are determined domestically based on the domestic sectoral productivity and wage differentials. According to this hypothesis, an increase in domestic productivity of tradables will increase wages in this sector. Since wages equalize across traded and nontraded goods sectors, wages in nontraded goods sector will also increase. As prices of tradable goods are exogenous to the system, increased relative price of nontradable goods will increase overall price level in the economy, which will result in real exchange rate appreciation of the domestic currency (De Broeck and Slýk, 2001). Until now, however, researchers have used this model in explaining relative price changes and overlooked its role in explaining nominal exchange rate variability, which is also an important factor that explains fluctuations in real exchange rate in flexible exchange rate system (Mussa, 1986; Genberg and Swoboda, 1993; Obstfeld et al. 1995; Rogoff, 1996).

The main objective of this paper is to explore the linkages between nominal exchange rates and relative productivity differentials originating in Pakistan against its sixteen major trading partners - Australia, Belgium, Canada, France, Germany,

${ }^{1}$ Some other studies also establish the link between real factors and exchange rate movements (e.g. see Stulz, 1987; Cardia, 1991; Manzur, 1991; Lastrapes, 1992; Kollmann, 1995).

${ }^{2}$ Officer (1976) has named it as Productivity Bias Model. In literature it is also known as BalassaSamuelson Model, or Harrod-Balassa-Samuelson Model. 
Italy, Japan, Korea, Malaysia, Netherlands, Singapore, Sweden, Switzerland, Thailand, the United Kingdom and the United States - using quarterly time-series data for the flexible exchange rate period (1983Q1 to 2006Q4). ${ }^{3}$ The rapid productivity growth in the traded goods sector of Pakistan's major trading partners requires continuous adjustments in nominal and real exchange rates of Pakistan to keep the competitiveness of its exports.

The rest of the paper is organized as follows. Section II briefly reviews literature. Section III builds an econometric model. Quantitative implications of the model are examined in Section IV. Final section concludes the paper.

\section{Literature Review}

Earlier studies cast doubt about the validity of productivity bias hypothesis and differ widely in their conclusions about whether productivity differentials explain deviations from purchasing power parity (see e.g. De Vries, 1968; Clague and Tanzi, 1972; Officer, 1976). According to Officer (1974), results against productivity bias hypothesis are due to ignoring the quality differences in nontraded commodities (specially, consumer services) among countries. Hsieh (1982) using time-series data predicted that productivity differentials in traded and non-traded goods at home and abroad explain much of the deviations of exchange rates from purchasing power parity. Hsieh claimed that the findings of Officer (1976) were against the productivity model because he applied cross-sectional data, which do not account for factors that are specific to each country. Moreover, Officer analyzed productivity bias hypothesis annually. It is very unlikely to work over short horizons because of price rigidity and sluggish wage adjustments (Tille et al., 2001). However, Balassa (1973) argued that productivity bias hypothesis is not applicable to less developed countries because of the differences between developed countries and less developed countries in the importance of nontraded goods, endowment of natural resources, height of tariffs and amount of capital inflow. These results indicate that inclusion of less developed countries in the sample would orient the test toward rejecting the productivity differenial hypothesis.

More recently, a number of studies have appeared that provide substantial evidence to support productivity bias hypothesis applying time-series, cross-section

\footnotetext{
${ }^{3}$ The trading partners are chosen on the basis of the trade shares of various countries with Pakistan.
} 
and panel techniques (see e.g. Chinn, 1997; Begum, 2000; Rother, 2000; Coricelli and Jazbec, 2001; De Broeck and Slýk, 2001; Halpern and Wyplosz, 2001; Tille et al., 2001; Egert, 2002a, 2002b; Egert et al., 2002). This evidence is robust when panel techniques are applied as compared to time-series and cross-section data. Some of the studies also identify demand-side effects as significant determinants of exchange rates along with supply side factors (i.e. productivity differentials).

However, the results differ by specification, sample and data type. Moreover, it is not clear how good is labor productivity as a proxy for factor productivity, the theoretically implied variable of interest. Similarly, the traded goods purchasing power parity, perfect capital mobility and inter-sectoral equalization of wages, ${ }^{4}$ which are the key assumptions of productivity bias hypothesis, are harder to confirm empirically so that demand factors also determine the exchange rates (Sýndergaard, 2003). Froot and Rogoff (1995) and Sýndergaard (2003) argued that the empirical evidence in favor of productivity bias hypothesis is weaker than commonly believed, especially when comparing exchange rates across industrialized countries over the post Bretton Woods period. In summing up the literature, one can conclude that there is some support for a productivity bias model of exchange rate determination. However, due to statistical and data limitations, one cannot conclude that there is a robust relationship between productivity differential and exchange rates.

While there have been a number of studies showing the effects of productivity differential on nominal exchange rates in developed economies, the existing body of literature on this effect in transition and developing countries is very small. Empirical work on nominal exchange rate in Pakistan is confined only to purchasing power parity (Ahmad and Ali, 1999; Ahmad and Khan, 2002; Ahmed, 1992; Bhatti, 1996, 1997), uncovered interest parity (Alam et al., 2001) or monetary models (Kemal and Haider, 2004) of exchange rate determination. The main problem with these models is that they overstate the role of monetary variables in determining nominal exchange rates and understate the role of real fundamentals like productivity improvements in exchange rate determinations. To our knowledge there has not been any systematic analysis to explore the nexus

${ }^{4}$ Several studies have documented substantial and persistent inter-industry wage differentials. For instance, see Bartel and Sicherman (1999), and Machin and Van Reenen (1998) for the link between technological shifts and changes in the wage structure, or Osburn (2000) for a survey. S?ndergaard (2003) argued that there has been tendency for traded sector wages to grow faster than nontraded sector wages. 
between nominal exchange rates and relative productivity at home and abroad in Pakistan. In this regard, the present study is an attempt to fill this gap by providing a detailed analysis of nominal exchange rate determination in Pakistan using the so-called productivity bias model of exchange rate determination against its sixteen major trading partners for the flexible exchange rate period.

\section{Theoretical Model}

Balassa and Samuelson identify the impact of productivity shocks in traded and non-traded goods on exchange rate fluctuations and purchasing power parity violations in a dynamic general equilibrium model..$^{5}$ They argue that when there is a gap in traded goods productivity between two countries, it creates a wedge between wages and prices that enlarges overtime. Eventually, it leads to a large gap between purchasing power parity based exchange rate and the equilibrium exchange rate, thereby originating the term Productivity Bias Hypothesis in purchasing power parity literature (Officer, 1976). Their proposition is that traded goods sector comes across more technological innovations as compared to nontraded goods sector so prices remain high in nontradables sector relative to tradables sector. As a result, currencies of technologically advanced countries and countries that grow faster appreciate. Therefore, according to Balassa and Samuelson supply side shocks, e.g. technological improvements that mainly originate in fast-growing countries, affect exchange rates.

The basic model is build upon a number of assumptions. First, there are two sectors in an economy, producing tradable $(T)$ and nontradable $(N)$ goods under perfect competition, with two different constant returns to scale Cobb-Douglas production functions.

$$
\begin{aligned}
& Y_{T t}=A_{T t} L_{T t}^{a} K_{T t}^{1-a} \\
& Y_{N t}=A_{N t} L_{N t}^{b} K_{N t}^{1-b}
\end{aligned}
$$

where $Y_{t}, A_{t}, L_{t}$ and $K_{t}$ stand for output, total factor productivity, labor and capital respectively; $a, 1-a, b$ and 1- $b$ are the coefficients of the respective variables; and where $0<a<1$ and $0<b<1$. Second, labor elasticity of production is larger in nontraded goods sector than in traded goods sector i.e. $b>a$. Third, the prices of

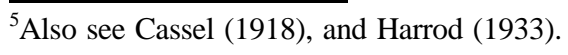


traded goods are determined in the world market so they are exogenous to the model, that is, purchasing power parity holds in traded goods prices. ${ }^{6}$ Fourth, interest rate parity holds due to international capital markets integration. Fifth, capital stock is fixed for one period ahead. Sixth, labor is perfectly mobile across sectors but less mobile at the international level. Seventh, real wages in the traded goods sector are determined by the marginal products and because of the wage equalization process in the economy the nominal wages paid in the traded goods sector also hold for the nontraded goods sector. Finally, preference structures in home and foreign countries are assumed to be given by Cobb-Douglas utility function of the representative agents. Several papers have derived the equations for the determination of real exchange rate based on the above set of assumptions. ${ }^{7}$ It can be shown that under the same general framework the behavior of nominal exchange rate would be governed by the following equation. ${ }^{8}$

$$
\begin{aligned}
e_{t}= & \beta_{l}+\beta_{2}\left(p_{t}^{*}-p_{t}\right)+\beta_{3}\left(x_{T t}-x_{N t}\right)+\beta_{4}\left(x_{T t}^{*}-x_{N t}^{*}\right)+\mu_{t} \\
& \mu_{t} \sim\left(0, \sigma^{2}\right)
\end{aligned}
$$

where $e_{t}, p_{t}, x_{T t}$ and $x_{N t}$ denote natural logs of nominal exchange rate, domestic price level, average productivity of labor in traded and nontraded goods sectors respectively, while the superscript $*$ indicates that the variables belong to the foreign country. It is expected that $\beta_{2}(=-1)<0, \beta_{3}<0, \beta_{4}>0$, while $\beta_{1}$ can take any real value.

If foreign price level increases faster relative to domestic price level then the real exchange rate will depreciate, thereby enhancing international competitiveness of the home country. However, the resulting increase in net exports will ultimately lead to nominal appreciation of domestic currency. Thus, the relative price term $\left(p_{t}^{*}-p_{t}\right)$ is presumed to be inversely related to nominal exchange rate.

An increase in productivity of domestic traded goods sector relative to the productivity of home nontraded goods sector causes workers to move from the nontradables to the more productive tradables sector, so that domestic output of the traded goods increases and home firms are able to reduce tradables' prices. The exports of domestic tradables will boost up, which will improve trade balance.

\footnotetext{
${ }^{6}$ In almost all cases, the price of any tradable good has a nontradable component. To the extent that the labor cost involved in distribution and sales is lower in a developing country, final prices may not be equalized across countries even for fully tradable goods.

${ }^{7}$ See, in particular, Chinn (1997), Begum (2000), De Broeck and Sløk (2001), Egert et al. (2002), etc. ${ }^{8}$ Full derivation of the model is available from the authors.
} 
Domestic currency will appreciate in nominal terms via improved trade balance so that purchasing power parity continues to hold for traded goods' sector (Kim, 1990; Rother, 2000; Søndergaard, 2003). Thus, the domestic relative productivity term $\left(x_{T t}-x_{N t}\right)$ is expected to be negatively related to nominal exchange rate. ${ }^{9}$

A similar interpretation holds if productivity originates in traded goods sectors relative to productivity in nontraded goods sector in foreign country. An increase in traded goods productivity of the foreign country will appreciate foreign currency in nominal terms, which indicates the depreciation of domestic currency. Thus, a positive relationship is contemplated between domestic nominal exchange rate and the foreign relative productivity term $\left(x_{T t}^{*}-x_{N_{t}}^{*}\right)$.

\section{Data, Estimation and Results}

We have collected quarterly data for sixteen major trading partners of Pakistan Australia, Belgium, Canada, France, Germany, Italy, Japan, Korea, Malaysia, Netherlands, Singapore, Sweden, Switzerland, Thailand, the United Kingdom and the United States - for the flexible exchange rate period (1983 to 2006). This yields a total of 96 quarterly observations for testing validity of the model with each of the trading partners of Pakistan. Exchange rate has been defined as domestic currency units per unit of foreign currency. Domestic and foreign inflation rates are proxied by growth rates of consumer price indexes. Sectoral productivity (i.e. productivity in traded and non-traded sectors) is defined as the ratio of GDP (at constant prices) originating in that sector to total employment in that sector (i.e. average productivity). ${ }^{10}$ Different researchers have used different proxies to define tradables and nontradables sectors as no consensus has been reached in the literature on this issue. ${ }^{11}$ Table 1 summarizes sector-wise classification of traded and non-traded goods applied by various studies.

\footnotetext{
${ }^{9}$ The results for the exchange rate depend to a large extent on the elasticity of substitution between tradables and nontradables. With higher elasticity of substitutability between tradables and nontradables, the exchange rate becomes less responsive to productivity shocks, both in the short-run and in the long run, and vice-versa for lower substitutability (Richards and Tersman, 1996).

${ }^{10} \mathrm{We}$ have used average productivity rather than marginal productivity because it is easier to get reliable data on former than latter. Furthermore, with Cobb-Douglas technology marginal product is proportional to the average product.

${ }^{11}$ As Engel (1999) points out, the price of any good is in reality the price of a joint product: the good itself as well as the price of the associated marketing service. And, while the good might be a tradable commodity, the marketing service should be regarded as a nontraded good.
} 
Table 1. An Overview of Sector-Wise Classification of Traded versus Non-Traded Goods Adopted by Different Studies

\begin{tabular}{|c|c|c|}
\hline Studies & Traded Goods Sector & Non-Traded Goods Sector \\
\hline Balassa (1964), Hsieh (1982) & Manufacturing & All other sectors \\
\hline De Broeck and Sløk (2001) & Manufacturing, Construction & Services \\
\hline Begum (2000) & Manufacturing & Services \\
\hline $\begin{array}{l}\text { Tille et al. (2001), Officer } \\
\text { (1976) }\end{array}$ & $\begin{array}{l}\text { Manufacturing, Agriculture, } \\
\text { Hunting, Forestry, Fishing, } \\
\text { Mining and Quarrying }\end{array}$ & All other sectors \\
\hline $\begin{array}{l}\text { De Gregorio and Wolf (1994), } \\
\text { Chinn (1997) }\end{array}$ & $\begin{array}{l}\text { Manufacturing, Agriculture, } \\
\text { Mining, Transportation }\end{array}$ & All other sectors \\
\hline $\begin{array}{l}\text { Rother (2000), Strauss (1995, } \\
\text { 1996) }\end{array}$ & Manufacturing & $\begin{array}{l}\text { All other sectors (excluding } \\
\text { agriculture) }\end{array}$ \\
\hline Søndergaard (2003) & Manufacturing & $\begin{array}{l}\text { All other sectors } \\
\text { (excluding agriculture, min- } \\
\text { ing and public sector) }\end{array}$ \\
\hline Egert et al. (2002) & Agriculture, Manufacturing & All other sectors \\
\hline Marston (1986) & Manufacturing, Agriculture & All other sectors \\
\hline Present Study & $\begin{array}{l}\text { Industry (Manufacturing, } \\
\text { Construction, Mining, Elec- } \\
\text { tricity, Water, Gas) }\end{array}$ & $\begin{array}{l}\text { Services } \\
\text { (all other sectors excluding } \\
\text { agriculture) }\end{array}$ \\
\hline
\end{tabular}

The choice of tradable and non-tradable sectors depends to a great extent on the availability of the data and the nature of the particular country i.e. whether it is an industrialized or an agriculture-based country. We have considered industry (it comprises manufacturing, construction, mining, electricity, water and gas sectors) as tradable sector as our analysis include developed industrialized countries whose exports are mainly manufactured goods, ${ }^{12}$ while services (it comprises all other sectors except agriculture that includes forestry, hunting, fishing, cultivation of crops and livestock production) is taken as the nontradable sector. The crude data have been collected from various issues of International Financial Statistics (International Financial Corporation), World Development Indicators (World Bank) and Economic Survey (Government of Pakistan).

While estimating the model (equation 3), there are two econometric issues that need to be tackled. The first issue is to confirm whether or not the estimated equation represents a long-run stable relationship. This issue can be handled easily with the standard tools of co-integrating analysis available in literature. The second

${ }^{12}$ Egert et al. (2002) also propose that it is better not to consider agriculture sector as traded goods sector. 
issue has to do with endogeneity problem. Specifically the relative price between the two trading partners appearing on the right hand side of equation 3 is itself affected by changes in nominal exchange rate via its effect on prices of imported goods denominated in home currency units. This imported inflation can fuel inflation in general price level, especially when the imported goods include raw material and other intermediate goods. Furthermore, the productivity variable, as measured by the ratio of GDP to number of workers employed, can also be affected by changes in exchange rate through the potential real effects of exchange rate variations. In order to tackle the endogeneity problem, Generalized Method of Moments (GMM) estimation technique is adopted with lagged values of the variables involved used as instruments.

Note that our interest lies in testing the validity of productivity bias model for each trading partner of Pakistan. Therefore, the model is to be estimated for each trading partner one by one. This analysis, as opposed to the analysis based on panel data estimation, provides useful information regarding Pakistan's trade potential based on productivity differential with each country. Thus, the estimation follows three-step procedure as outlined below.

1. At the first step stationarity properties of all the variables are analyzed on the basis of standard Augmented Dickey-Fuller (ADF) unit-root test. If all variables are found to be integrated of order one, it will indicate that the estimated nominal exchange rate equation could possibly form a long-run relationship of nominal exchange rate with relative price levels and relative productivity levels at home and abroad.

2. At the second step co-integrating equation (3) is estimated. Since endogeneity problem is likely to arise in our right hand side variables, we apply GMM estimation technique of Arellano and Bond (1991) and Arellano (1993) using lagged values of independent variables used as instruments.

3. The third step is to apply the ADF tests on the regression residuals in order to confirm whether or not the estimated equations in step 2 form long-run relationships.

The ADF tests confirm that all the variables are integrated of order one; therefore they can form a long run relationship. ${ }^{13}$ Thus equation 3 is estimated with each of the 16 trading partners of Pakistan, the results of which are discussed shortly. Finally, the regression errors of the estimated equation are also found to be

\footnotetext{
${ }^{13}$ The results of ADF tests are not presented to conserve space.
} 
stationary on the basis of ADF tests, thereby confirming the existence of long-run relationships.

Table 2 provides the estimated results of the productivity bias model of exchange rate determination. Table 2 shows that most of the parameter estimates have theoretically expected signs and are statistically significant. For each country high values of R-square $\left(R^{2}\right)$ and adjusted R-square $\left(\bar{R}^{2}\right)$ indicate that the model fits the data quite well. Autoregressive (AR) process has been applied to remove autocorrelation in the model. In almost all the estimated regression equations Durbin-Watson (DW) statistics are approximately close to the desired value of two, indicating the absence of autocorrelation problem. However, for Korea, we cannot ignore the possibility of the presence of autocorrelation.

The regression coefficients of relative foreign price term $\left(p_{t}^{*}-p_{t}\right)$ have the expected negative sign in almost all regression specifications and are statistically significant, indicating that increase in foreign prices relative to Pakistan's price level have caused appreciation of the bilateral exchange rates of Pak-rupee through improved current account positions with the respective trading partners. These results support Ahmad and Khan (2002), Engel (1999) and MacDonald (1995) that long-run purchasing power parity holds in flexible exchange rate regime. For Italy and Sweden this variable appears with positive sign but it is significant only for the former. In more than half of the cases the coefficients of the relative price term significantly differ from the desired value of unity. A possible explanation is that there have been real disturbances and capital movements during the flexible exchange rate period that gives us these results (MacDonald, 1995).

An increase in relative productivity of Pakistan's tradables' sector $\left(x_{T t}-x_{N t}\right)$ has appreciated its currency in nominal terms against the currencies of its almost all trading partners via improved current account balance and in most of the cases this term is statistically significant. In turn, increased relative traded goods productivity abroad $\left(x_{T t}^{*}-x_{N t}^{*}\right)$ has depreciated Pak-rupee against the currencies of its almost all trading partners and in most of the cases this term is statistically significant. Both developments can be explained in terms of productivity bias model, which predicts that, irrespective of their direction, changes in productivity in the tradable sector will affect nominal exchange rates. These results corroborate Rother's (2000) findings that in flexible exchange rate system productivity improvements appreciate nominal exchange rates. The analysis tentatively suggests that as Pakistan embarks on a path of sustained growth, it will experience nominal and 
Table 2. Empirical Findings of Productivity Bias Model of Nominal Exchange Rate Determination with Major Trading Partners of Pakistan (1983Q1 - 2006Q4)

\begin{tabular}{|c|c|c|c|c|c|c|c|c|}
\hline & Constant & $p_{t}^{*}-p_{t}$ & $x_{T t}-x_{N t}$ & $x_{T t}^{*}-x_{N t}^{*}$ & $\mathrm{AR}(1)$ & $\mathrm{R}^{2}$ & $\overline{\mathrm{R}}^{2}$ & DW \\
\hline Australia & $\begin{array}{c}4.2572 \\
(21.9156)^{*}\end{array}$ & $\begin{array}{c}-1.4207 \\
(-12.8823)^{*}\end{array}$ & $\begin{array}{c}-0.6551 \\
(-1.6267)^{* *}\end{array}$ & $\begin{array}{c}3.2959 \\
(3.4364)^{*}\end{array}$ & $\begin{array}{c}0.7691 \\
(10.8577)^{*}\end{array}$ & 0.9680 & 0.9663 & 2.0784 \\
\hline Belgium & $\begin{array}{c}0.2249 \\
(1.6950)^{* *}\end{array}$ & $\begin{array}{l}-1.6693 \\
(-5.5211)^{*}\end{array}$ & $\begin{array}{c}-0.0615 \\
(-2.1378)^{*}\end{array}$ & $\begin{array}{c}1.8760 \\
(2.0044)^{*}\end{array}$ & $\begin{array}{c}0.9226 \\
(27.3484)^{*}\end{array}$ & 0.9884 & 0.9878 & 1.9332 \\
\hline Canada & $\begin{array}{c}3.2740 \\
(14.9653)^{*}\end{array}$ & $\begin{array}{c}-0.9719 \\
(-2.9488)^{*}\end{array}$ & $\begin{array}{c}-0.7241 \\
(-2.2398)^{*}\end{array}$ & $\begin{array}{c}0.3651 \\
(2.8031)^{*}\end{array}$ & $\begin{array}{c}0.9420 \\
(26.2362)^{*}\end{array}$ & 0.9901 & 0.9896 & 1.9564 \\
\hline France & $\begin{array}{c}2.0762 \\
(9.0674)^{*}\end{array}$ & $\begin{array}{c}-1.3961 \\
(-5.2707)^{*}\end{array}$ & $\begin{array}{c}-0.9413 \\
(-2.2735)^{*}\end{array}$ & $\begin{array}{c}1.3290 \\
(2.2521)^{*}\end{array}$ & $\begin{array}{c}0.9112 \\
(15.0890)^{*}\end{array}$ & 0.9874 & 0.9868 & 2.1231 \\
\hline Germany & $\begin{array}{c}4.0669 \\
(48.9484)^{*}\end{array}$ & $\begin{array}{c}-0.9117 \\
(-7.0116)^{*}\end{array}$ & $\begin{array}{c}-0.4013 \\
(-1.7644)^{* *}\end{array}$ & $\begin{array}{c}4.2667 \\
(8.1724)^{*}\end{array}$ & $\begin{array}{c}0.7211 \\
(13.7278)^{*}\end{array}$ & 0.9876 & 0.9869 & 1.8334 \\
\hline Italy & $\begin{array}{c}1.8661 \\
(0.1515)\end{array}$ & $\begin{array}{c}1.3166 \\
(1.8707)^{* *}\end{array}$ & $\begin{array}{c}0.3023 \\
(0.3547)\end{array}$ & $\begin{array}{c}1.2832 \\
(1.3984)\end{array}$ & $\begin{array}{c}0.9942 \\
(84.5717)^{*}\end{array}$ & 0.9785 & 0.9773 & 1.9905 \\
\hline Japan & $\begin{array}{c}-0.5752 \\
(-4.7681)^{*}\end{array}$ & $\begin{array}{c}-1.1535 \\
(-5.4555)^{*}\end{array}$ & $\begin{array}{c}0.8467 \\
(1.6581)^{\text {** }}\end{array}$ & $\begin{array}{c}-1.1323 \\
(-0.7439)\end{array}$ & $\begin{array}{c}0.8765 \\
(19.0666)^{*}\end{array}$ & 0.9882 & 0.9876 & 1.8676 \\
\hline Korea & $\begin{array}{c}-1.9911 \\
(-6.4274)^{*}\end{array}$ & $\begin{array}{c}-3.2285 \\
(-5.7447)^{*}\end{array}$ & $\begin{array}{c}-0.4623 \\
(-2.0417)^{*}\end{array}$ & $\begin{array}{l}2.1854 \\
(3.2251)^{*}\end{array}$ & $\begin{array}{c}0.7330 \\
(9.3899)^{*}\end{array}$ & 0.9171 & 0.9126 & 2.4885 \\
\hline Malaysia & $\begin{array}{c}2.8313 \\
(55.6390)^{*}\end{array}$ & $\begin{array}{c}-1.2512 \\
(-17.8664)^{*}\end{array}$ & $\begin{array}{c}-0.5543 \\
(-3.8295)^{*}\end{array}$ & $\begin{array}{c}0.4865 \\
(3.7808)^{*}\end{array}$ & $\begin{array}{c}0.6973 \\
(10.4922)^{*}\end{array}$ & 0.9818 & 0.9809 & 1.8504 \\
\hline $\begin{array}{l}\text { Nether- } \\
\text { lands }\end{array}$ & $\begin{array}{c}3.6421 \\
(19.7821)^{*}\end{array}$ & $\begin{array}{c}-2.0068 \\
(-6.2411)^{*}\end{array}$ & $\begin{array}{c}-1.5947 \\
(-1.7169)^{* *}\end{array}$ & $\begin{array}{c}1.3865 \\
(2.6153)^{*}\end{array}$ & $\begin{array}{c}0.9202 \\
(18.8489)^{*}\end{array}$ & & 0.9835 & 1.9613 \\
\hline & $\begin{array}{c}3.5443 \\
(75.4188)^{*}\end{array}$ & $\begin{array}{c}-1.3554 \\
(-17.0578)^{*}\end{array}$ & $\begin{array}{c}-0.6138 \\
(-3.3814)^{*}\end{array}$ & $\begin{array}{c}-0.0716 \\
(-0.6532)\end{array}$ & $\begin{array}{c}0.8143 \\
(11.0976)^{*}\end{array}$ & 0.9945 & 0.9942 & 1.8052 \\
\hline Sweden & $\begin{array}{c}3.6380 \\
(1.7347)^{* *}\end{array}$ & $\begin{array}{c}0.2259 \\
(0.1895)\end{array}$ & $\begin{array}{c}-1.6613 \\
(-1.7461)^{* *}\end{array}$ & $\begin{array}{c}3.1602 \\
(2.0008)^{*}\end{array}$ & $\begin{array}{c}0.9841 \\
(71.2172)^{*}\end{array}$ & 0.9621 & 0.9601 & 1.9783 \\
\hline $\begin{array}{l}\text { Switzer- } \\
\text { land }\end{array}$ & $\begin{array}{c}3.2213 \\
(13.7632)^{*}\end{array}$ & $\begin{array}{l}-1.1166 \\
(-4.3818)^{*}\end{array}$ & $\begin{array}{c}-0.4052 \\
(-0.5482)\end{array}$ & $\begin{array}{c}1.7195 \\
(1.9798)^{* *}\end{array}$ & $\begin{array}{c}0.9110 \\
(13.5196)^{*}\end{array}$ & 0.9892 & 0.9886 & 2.1261 \\
\hline Thailand & $\begin{array}{c}0.6082 \\
(8.8776)^{*}\end{array}$ & $\begin{array}{c}-1.3904 \\
(-12.2027)^{*}\end{array}$ & $\begin{array}{c}-0.3703 \\
(-2.5769)^{*}\end{array}$ & $\begin{array}{c}0.5276 \\
(2.5530)^{*}\end{array}$ & $\begin{array}{c}0.6860 \\
(9.8007)^{*}\end{array}$ & 0.9663 & 0.9645 & 1.7907 \\
\hline $\begin{array}{l}\text { United } \\
\text { Kingdom }\end{array}$ & $\begin{array}{c}4.2561 \\
(14.2656)^{*}\end{array}$ & $\begin{array}{c}-1.5479 \\
(-1.9457)^{* *}\end{array}$ & $\begin{array}{c}-1.2704 \\
(-2.1980)^{*}\end{array}$ & $\begin{array}{c}-0.8299 \\
(-0.8124)\end{array}$ & $\begin{array}{c}0.9417 \\
(17.5723)^{*}\end{array}$ & 0.9842 & 0.9833 & 1.8440 \\
\hline $\begin{array}{l}\text { United } \\
\text { States }\end{array}$ & $\begin{array}{c}3.8326 \\
(68.2605)^{*}\end{array}$ & $\begin{array}{c}-1.6400 \\
(-10.1386)^{*}\end{array}$ & $\begin{array}{c}-0.4064 \\
(-1.9439)^{* *}\end{array}$ & $\begin{array}{c}0.7818 \\
(1.4496)\end{array}$ & $\begin{array}{c}0.9237 \\
(32.2513)^{*}\end{array}$ & 0.9951 & 0.9949 & 1.8586 \\
\hline
\end{tabular}

Note: Values in parentheses show $t$-statistics. The statistics significant at $5 \%$ and $10 \%$ levels of significance are indicated by $*$ and $* *$ respectively.

real exchange rate appreciations. Nevertheless, these results should be taken with some caution because for a few countries productivity variables appeared with reverse signs (Italy, Japan, Singapore, United Kingdom). It indicates the absence of Pakistan's trade potential with these countries based on productivity differentials. 


\section{Conclusion}

In this paper a simple two-country model with traded and nontraded goods sector has been developed to examine the impact of productivity improvements in traded and nontraded goods sectors (emanating both at home and abroad) on Pakrupee nominal exchange rates for flexible exchange rate period (1983 to 2006). The results predict a close relationship between nominal exchange rates, relative price differentials and, relative domestic and foreign productivity differentials. First, it appears that relative price levels explain part of the long-run movements of Pak-rupee nominal exchange rates. It supports Engel (1999), Kim (1990) and MacDonald (1995) that purchasing power parity holds to a considerable extent in flexible exchange rate regime. Second, increases in the domestic (foreign) relative productivity of traded goods sector lead to an appreciation (depreciation) of nominal exchange rates. Thus, the long-run movements in Pak-rupee nominal exchange rates appear to be fully explained by sectoral productivity differentials under modern flexible exchange rate regime. The findings in this paper are in accordance with Rother's (2000) findings that in flexible exchange rate system productivity improvements lead to appreciation of the nominal rates. Our findings invalidate Balassa's (1973) argument regarding the inapplicability of productivity bias hypothesis to less developed countries. Rather, our findings support Hsieh's (1982) findings that productivity bias model holds if time-series analysis is undertaken.

Thus, the nominal exchange rate is found to be another channel through which productivity differentials affect real exchange rates other than inflation rates. These results have important policy implications. Nominal exchange rate appreciations that reflect productivity gains in the tradable sector are an equilibrium phenomenon and do not erode competitiveness. Rather, the analysis of competitiveness in the traded goods sector should focus on production costs in that sector. ${ }^{14}$ In the transition economies, these appreciations reflect progress in their becoming fullfledged market economies, and they do not require a policy response.

Of course there are also some other sources, particularly the demand-side factors that can explain movements in nominal exchange rates of Pak-rupee. The most important of these factors is the extent of currency convertibility, that is, the

\footnotetext{
${ }^{14}$ The real exchange rate based on unit labor costs (ULC) represents one common tool for this analysis as it captures a large part of those costs. It should be noted that the CPI-based real exchange rate reflects changes in total factor productivity while the ULC-based indicator is based on labor productivity.
} 
amount of permitted current and capital account transactions, the ability and willingness of central banks to sterilize capital inflows, and the use of the exchange rate for macroeconomic stabilization or trade balance developments. So demandside factors should be taken into account while explaining movements in exchange rates other than supply-side factors.

Received 4 March 2008, Revised 8 May 2008, Accepted 14 May 2008

\section{References}

Ahmad, E. and F. N. Khan(2002), "Short-run Dynamics in Purchasing Power Parity: a Case of Selected Asian Countries", Middle East Business and Economic Review, 14(2), pp. 28-40.

Ahmad, E. and S. A. Ali (1999), "Exchange Rate and Inflation Dynamics", The Pakistan Development Review, 38(3), pp. 235-51.

Ahmed, M.(1992), “Pakistan's Exchange Rate Policy: an Econometric Investigation”, The Pakistan Development Review, 31(1), pp. 49-74.

Alam, S., M. S. Butt and A. Iqbal(2001), "The Long-run Relationship between Real Exchange Rate and Real Interest Rate in Asian Countries: an Application of Panel Cointegration", The Pakistan Development Review, 40(4), pp. 577-602.

Arellano, M.(1993), "On Testing of Correlation Effects with Panel Data" Journal of Econometrics, 59 (1), pp. 87-97.

Arellano, M. and S. Bond (1991), "Some Tests of Specification for Panel Data: Monte Carlo Evidence and an Application to Employment Equations", Review of Economic Studies, 58, pp. 277-97.

Balassa, B.(1964), "The Purchasing-Power Parity Doctrine: a Reappraisal", Journal of Political Economy, 72(6), pp. 584-96.

Balassa, B.(1973), "Just How Misleading are Official Exchange Rate Conversions? a Comment”, Economic Journal, 83, pp. 1258-67.

Begum, J.(2000), "Real Exchange Rates and Productivity: Closed-Form Solutions and Some Empirical Evidence", IMF Working Paper No. 2000(99), Washington D.C.

Bhatti, R. H.(1996), "A Correct Test of the Purchasing Power Parity: the Case of PakRupee Exchange Rates", The Pakistan Development Review, 35(4), pp. 671-682.

Bhatti, R. H.(1997), "Do Expectations Play any Role in Determining Pak Rupee Exchange Rates?", The Pakistan Development Review, 36(3), pp. 263-73.

Cassel, G. (1918), "Abnormal Deviations in International Exchanges", Economic Journal, 28(4), pp. 413-15.

Chinn, M. D.(1997), "Sectoral Productivity, Government Spending and Real Exchange Rates: Empirical Evidence for OECD Countries", NBER Working Paper No. 1997(6017), Cambridge Mass. 
Clague, C. and V. Tanzi(1972), "Human Capital, Natural Resources and the Purchasing Power Parity Doctrine: Some Empirical Results", Economic Internazionale, 25, pp. 3-18.

Coricelli, F. and B. Jazbec(2001), "Real Exchange Rate Dynamics in Transition Economies", Discussion Paper No. 2001(2869), CEPR.

De Broeck, M. and A. Slýk(2001), "Interpreting Real Exchange Rate Movements in Transition Countries", IMF Working Paper, No. 2001(56), Washington D.C.

De Gregorio, J. and H. Wolf(1994), "Terms of Trade, Productivity, and the Real Exchange Rate", NBER Working Paper No. 1994(4807), Cambridge Mass.

De Vries, M. G.(1968), "Exchange Depreciation in Developing Countries", IMF Staff Papers, 15, pp. 560-78.

Egert, B.(2002a), "Estimating the Impact of the Balassa-Samuelson Effect on Inflation and the Real Exchange Rate during the Transition", Economic Systems, 26(1), pp. 116.

Egert, B.(2002b), "Investigating the Balassa-Samuelson Hypothesis in the Transition: Do We Understand What We See? a panel study", Economics of Transition, 10(2), pp. 273-309.

Egert, B., I. Drine, K. Lommatzsch and C. Rault(2002), "The Balassa-Samuelson Effect in Central and Eastern Europe: Myth or Reality?", William Davidson Working Paper No. 2002(483), Michigan University.

Engel, C.(1999), "Accounting for U.S Real Exchange Rate Changes", Journal of Political Economy, 107(3), pp. 507-38.

Froot, K. and K. Rogoff (1995), "Perspective on PPP and Long-Run Real Exchange Rates", in G. Grossman and K. Rogoff (eds.), Handbook of International Economics, (Elsevier: Amsterdam), 3, pp. 1648-84.

Genberg, H. and A. K. Swoboda(1993), "Fixed Versus Flexible Exchange Rates", in C. S. Nagpal and A. C. Mittal (eds.), International Monetary Theory, (New Delhi: Anmol Publications Pvt. Ltd., 1993), 132-160.

Halpern, L. and C. Wyplosz (2001), "Economic Transformation and Real Exchange Rates in the 2000s: the Balassa-Samuelson Connection", UNO Economic Survey of Europe, 2001(1), pp. 227-39.

Harrod, R. F.(1933), International Economics, London: James Nisbet and Cambridge University Press.

Hsieh, D. A.(1982), "The Determination of the Real Exchange Rate: The Productivity Approach", Journal of International Economics, 12, pp. 355-62.

Kemal, M. A. and R. M. Haider (2004), "Exchange Rate Behaviour after Recent Float: the Experience of Pakistan", The Pakistan Development Review, 43(4), pp. 829-852.

Kim, Y.(1990), "Purchasing Power Parity in the Long-run: A Cointegration Approach", Journal of Money, Credit and Banking, 22(4), pp. 491-503.

Macdonald, R.(1995), "Long-Run Exchange Rate Modeling", IMF Staff Papers, 42(3), pp. 437-89.

Marston R. C.(1986), "Real Exchange Rates and Productivity Growth in the United States 
and Japan", NBER Working Paper No. 1986(1922), Cambridge Mass.

Mussa, M.(1986), "Nominal Exchange Rate Regimes and the Behavior of Real Exchange Rates”, in K. Brunner and A. Meltzer (eds.), Real Business Cycles, Real Exchange Rates, and Actual Policies, (Carnegie Rochester Conference Series).

Obstfeld, M., R. Dornbusch and R. McKinnon(1995), "International Currency Experience: New Lessons and Lessons Relearned", Brookings Papers on Economic Activity, 1. pp. 199-220.

Officer, L. H.(1974), "Purchasing Power Parity and Factor Price Equalization", Kyklos, 27. pp. 868-78.

Officer, L. H.(1976), “The Productivity-bias in Purchasing Power Parity: an Econometric Investigation", International Monetary Fund Staff Papers, 23(3), pp. 545-79.

Rogoff, K.(1996), “The Purchasing Power Parity Puzzle”, Journal of Economic Literature, XXXIV, pp. 647-68.

Rother, P. C.(2000), "The Impact of Productivity Differentials on Inflation and the Real Exchange Rate: an Estimation of the Balassa-Samuelson Effect in Slovenia”, IMF Country Report No. 56, pp. 26-38.

Søndergaard, J.(2003), A Reinterpretation of the Harrod-Balassa-Samuelson Hypothesis in a Monopolistic Competition Framework, (Draft available at www.georgetown.edu./ users/sondergi/).

Samuelson, P. A.(1964), “Theoretical Notes on Trade Problems", The Review of Economics and Statistics, 46, pp. 145-54.

Strauss, J.(1995), "Real Exchange Rates, PPP and the Relative Price of Nontraded Goods", Southern Economic Journal, 61, pp. 991-1005.

Strauss, J.(1996), “The Cointegration Relationship between Productivity, Real Exchange Rates and Purchasing Power Parity", Journal of Macroeconomics, 18, pp. 299-313.

Tille, C., N. Stoffels and O. Gorbachev (2001), "To What Extent Does Productivity Drive the Dollar", Current Issues in Economics and Finance, 7(8), pp. 1-6. 